\title{
The Impact of COVID-19 Outbreak on Human Resource Operation: Empirical Evidence from the Perspective of Malaysian Retail Employees in Klang Valley
}

\author{
Md Suliman Hossin ${ }^{1 *}$, Ilham Sentosa ${ }^{2}$, Md Shuhel Miah ${ }^{3}$ \\ UniKL Business School, Universiti Kuala Lumpur, Malaysia
}

Keywords:

Covid-19, Job Depression, Job Anxiety, HR operation, Malaysia, PLS-SEM, Retail Industry

\section{Received}

18 October 2020

Received in revised form

10 November 2020

Accepted

23 November 2020

*Correspondence:

md.suliman@s.unikl.edu.my

\begin{abstract}
The aim of this research is to examine the Coivd-19 impacts on the Human Resource (HR) operation in the Malaysian retail sector, especially in the Klang Valley area. A selfadministered online survey was conducted with 330 participants answering. The partial least square approach to structural equation modeling (PLS-SEM) was used to investigate the direct effects of the proposed variables. Besides, the mediation test was used to examine the indirect effects. The outcomes of the study showed that the current pandemic has an essential influence on job depression and anxiety at the retail level. Furthermore, the direct relationship between Covid-19, salary, and layoff is significant, suggesting that COVID-19 is a severe problem for employees' salaries and layoffs. In contrast, the indirect effect of Covid19, job depression, job anxiety, salary, and layoff confirm a significant relationship with partial mediation. Job depression, however, does not mediate the relationship between COVID-19 and layoff. This research only considered Klang Valley area in addition to the data collected through the convenient sampling method by using an online survey form. The findings of the study offer an insight into the factors influencing human capital management and how the retail decision-makers, retailers, retail consultants, and staff should devise a new approach to adjust HR policies in a 'new normal' situation. The study adds to the existing knowledge about the effect of Covid-19 on job depression, job anxiety, salaries, and layoffs among retail employees. This study will also provide a source of further research because the area under investigation is new in the current pandemic situation.
\end{abstract}

COVID-19, a worldwide pandemic, is traveling 190 countries with a rising number of the death toll. This SARS-COV2 virus first came into notice in Wuhan, China, in November 2019. The very first case of the corona virus-infected patient was found on 17 November 2019 in Wuhan 
(Davidson, 2020). The devastating effect of Covid-19, which originated from China, is now creating global pandemic and taking valuable lives across countries. Till April, this deadly virus has killed more than 160,000 people and 2,278,693 more infected. Since February 2020, as the number of corona virus-infected people along with the death numbers were rising, hence in March 2020, the World Health Organization (WHO) declared Covid-19 as a global pandemic. The ripple effect of the new coronavirus (Covid-19) from China produces rampant shock waves everywhere in the world, which affects approximately every walk of society that we know today. COVID-19 is affecting the global economy negatively (McKibbin \& Fernando, 2020). Since the beginning of widespread COVID-19, almost all the countries implemented lockdown or movement control order (MCO) or Isolation and home quarantine to reduce the spread of these lives taking virus. Thus, all sorts of institutions were closed, including shopping malls, small retail shops, mills, warehouses, offices, courts, restaurants, hotels, schools, colleges, universities, and religious institutions. As a result, people have become prisoners in the house (Welt et al., 2020). However, the global economy has seen the worst effect of the Corona Virus, as all the businesses, markets, and import-export have been closed. Because of which many people become jobless, and few have seen salary cut situation. The worst affected sectors are retail, food, and readymade garments industry. Thousands of individuals across the world have lost their jobs; as a result, they are going through a very critical period, due to lack of income (Baker, Farrokhnia, Meyer, Pagel, \& Yannelis, 2020). With regard to the retail sector, where millions of employees in Malaysia, work as full-time, part-time, and contractual conditions lead to loss of employment. Part-time and contract employees have already begun to lose their jobs where full-time employees are faced with a wage reduction or a delay in payment. This crisis situation will have a great negative impact on employee's performance and will increase job dissatisfaction though the Malaysian government announced Recovery Movement Control Order (RMCO) on June 10, 2020, and allowed business institutes to operate their operation by following strict SOPs. Hence this RMCO will exist till August 31, 2020 (Loo, 2020), so there is a possibility that still retail cannot operate their business in a full-fledged way, besides under the present situation, the number of customers will also be less. So, the retail business will face severe economic depression; for this reason, retail employees may face salary reductions with anxiety to lose jobs.

\section{Impact of COVID-19 on Malaysian Retail Sector}

It is reported that due to the COVID-19 issue, Malaysia's retail industry has contracted by $18.8 \%$ in January - March 2020. This is considered its biggest-ever quarterly contraction since 1998. According to Retail Group Malaysia (RGM), retailers took a hit from the COVID-19 and Movement Control Order (MCO) in Malaysia (Basari, Yazid, \& Shamsudin, 2020). According to RGM, the fear of pandemic begun to affect consumer spending, followed by the MCO, which caused non-essential retailers to clock in zero sales. Retailers that offer worth arranged brands and markdown retailers are probably going to profit by this circumstance, at any rate during this monetary downturn, while extravagance and very good quality retailers will probably endure. It will be significant for retailers to comprehend what shoppers see as being fundamental and what they consider to be an extravagance. It is basic for these insignificant or extravagance retailers to keep fabricating their image and drawing in with online customers (Roggeveen \& Sethuraman, 2020). 
The COVID-19 catastrophe has been psychologically challenging for many people, changing day-to-day life in unprecedented ways. The coronavirus crisis is a narrative with an unclear ending. What is evident is that the human effect is already unfortunate and that companies have an imperative to act instantly to safeguard their employees, address business challenges and risks, and help to alleviate the outbreak in whatever ways they can (Craven, Liu, Mysore, \& Wilson, 2020). Unsurprisingly retail sector is suffering to different degrees. In this pessimistic scenario, the depression and anxiety rising among employees as this is not seasonal and continues to grow throughout 2020. However, employees start responding to this crisis in different ways. When faced with an uncertain, risky situation over which in no way control, people try their best to survive. There are some psychological factors like future job uncertainty, rising number of covid19 patient each day in every states and in few cases death of close friends and family members contributing to this situation. However, during this pandemic situation, there are added layers of personal crisis (Meyer, 2020). There is an impending financial crisis coming about because of this pandemic. Job losses are mounting, and economies are contracting the world over. With the loss of employment, customer spending diminishes, which thusly makes different organizations endure and more individuals to lose their jobs.

\section{Literature Review and Hypothesis Development Human Resource Operation in Malaysia}

Human resource operation of any organization includes the day to day HR activities and strategic HR actions to keep the institutes in operation. Ponnusamy (2019) mentioned, to maintain the business process, whatever the services the HR department provides are considered as HR operations. In general, HR operation includes the daily HR activities, recruitment, job analysis, performance appraisal, termination, employee training and development, employee welfare management, salary, and employee relationship management. Besides, the paradigm of HR operation is more dynamic and vastly extensive. However, few people do not appreciate the contribution of the HR team, yet the HR department, in most cases, works beyond their job description. HR operations are, in most cases, undervalued (Haak, 2017). HR practices in Malaysia are somewhat stable and subject to government scrutiny; employees, therefore, enjoy fundamental rights. However, under the present unwanted situation, HR department has come in front of the fire line as HR keeps the balance between employers and employees. The HR activity involves a great deal of research, but salaries and turnover have become a critical center of debate in the emerging pandemic situation in Malaysia's retail sector. Salary is one of the essential elements of HR, and the other one is a layoff. Due to this virus attack, workers do not consistently earn their wages and spend fear at any point to lose their jobs.

\section{Salary}

Salary is a critical element for any employee and business organization. Employees invest their time and effort to earn a reasonable livelihood. If the organization is unable to pay on time, then employees become dissatisfied, and sometimes they leave the organization. Especially with the current disastrous state of outages for all businesses over the past three months, most of the retail organizations could not pay their employees on time. Besides, the overwhelming majority of retailers have asked the staff to take unpaid leave while very few companies have given their employees a reduced salary. Hence, the Malaysian Retail Association (MRA) president James Loke has said, "The retail and franchise industries and related businesses are facing 
unprecedented uncertainties due to the ongoing MCO. It has brought big losses to businesses, and workers are being laid off" (Perimbanayagam, 2020).

For any type of business, salary plays a vital role in retaining employees and establish a good employee and employer relationship. So, it is clear that salary somehow shapes the behavior of an employee. That's why Hung, Lee, and Lee (2018) mentioned; salary satisfaction refers to employees' attitude towards generated salaries, this attitude will affect individual employees' salaries and working relationships between the relevant output behaviors. Besides, Regular and good wage practices help organizations to improve the motivation and organizational commitment of employees, which ultimately increases employee productivity and satisfaction (Iqbal, Guohao, \& Akhtar, 2017). If employees get a salary even under a bad economic situation, then they become more satisfied and loyal to the employers. Employees' pay satisfaction has a significant impact on employee performance and job satisfaction (Ting, 1997). However, Judge, Cable, and Higgins (2000) mentioned, several studies have found that pay contentment has a positive effect on overall job satisfaction, motivation, and performance, and results in less absenteeism and reduced turnover behaviors. In the current pandemic, retailers who pay their employees consistently will minimize possible future staff turnover and will dramatically increase their loyalty to the company as wages will impact the employee's emotional state related to anxiety and depression. Salary is somehow associated with the psychological situation of employees; hence, a poor pay system can increase employee depression and anxiety, which can significantly raise high employee attrition (Chaudry et al., 2018).

\section{Layoff}

Job loss is commonly recognized as a detrimental traumatic incident attributed to the resulting downturn in economy and unemployment (Pohlan, 2019). Layoffs are a problematic event in the lives of laid-off employees who report psychological depression, life dissatisfaction, and physical, social, and economic problems (Sobieralski \& Nordstrom, 2012). Due to the COVID-19 effect across the globe, people have started losing their job. The retail industry has poorly affected due to the lockdown situation. This industry is a customer-oriented sector where business exist if customers come or else organization goes out of business. Under the present lockdown phenomena, the retail organization has faced almost zero sales; hence it has become the utmost difficulty for them to give salary to the employees. On the other hand, employees without pay are in a big dilemma to survive. This turmoil situation is getting worst as the Malaysian retail sector accommodated more foreign employees as part-time, full-time, and contractual employees. Malaysian Retail Chain Association president Datuk Gary Chua mentioned, "Many retailers are already implementing cost cuts, at least 80 percent; thus, it is expected that 30 percent workers may face lay off in the next six month" (Zahid, 2020). If the employee layoff starts then, the organization may lose its reputation in society and face financial losses in the future due to the lack of skilled employees. For this reason Malik, Ahmad, and Hussain (2010) stated that downsizing from jobs increases disloyalty, work insecurity, anxiety, depression, and frustration, raising the question of the reputation of the organization and rising staff turnover costs. If the practices of downsizing carry on, then there are high chances that employees will lose confidence in the organization beside organization may lose social acceptance and lower the effort to achieve the organizational goal. When workers are not happy and worry about being fired, decreased quantity and quality of work are inevitable (Reinardy, 2012). 


\section{COVID-19}

Coronavirus or COVID-19 is considered one of the most rapid infectious diseases which originated in Wuhan, China, last year. This, without any doubt, has a global impact, including Malaysia. The business sector is no longer as usual, and the seriousness of the impact is very obvious, even in the retail sector of Malaysia. The Covid-19 outbreak has had an impact on companies of all sizes and sectors of all kinds. Due to the high contagion risk of a recent pandemic, the Malaysian government announced a Movement Control Order (MCO) on 18 March. In addition to essential services, almost all financial activities have been shut down.

The impacts of the COVID-19 outbreak on the retail industry in Malaysia is quite significant and completely unexpected. The pandemic of COVID-19 has forced the retail outlets of the nation to remain closed (Hasanat et al., 2020). Many companies are now finding it hard to keep up their monthly expenses. This situation has identified to be unparalleled disruption of retail businesses. All the major cities have declared self-isolated, lockdown, social distancing have directed their employees in depressions and anxiety. On top of that, retailers are not paying on time rather laying off their employees. Besides, this approach affecting retail employees, and the impacts fall into two major categories, the first being the actual impacts on public health on individuals, on the employees in retail and food services, and individuals going throughout the rest of the supply chain. The second one is the dramatic change in what and where people used to buy- the shops. Though there is an immediate impact of COVID-19 on the retail industry, there is a remarkable uncertain projection in the future. The new normal is implausible to be the same as life was in January 2020.

\section{Job Depression}

COVID-19 is creating havoc in the business sector globally, including Malaysia. This has reflected a tremendous effect in the retail industry, among others, in Malaysia. Employees are restricted from working. In this uncertain environment, it has become very challenging for HR to deal with the challenges of the effects of COVID-19 on the Management and Employees. Financial constraint, disruption in the workplace, global pandemic, lockdown situations are leading the employees in depressed life. Depression is highly rampant syndromes with an impact on existential traits of a person's life and work-life (Gilmour \& Patten, 2007; Ivandic et al., 2017).

Due to the outbreak of COVID-19, one of the concerns that the HR department of every company is expected to fulfill, something that has lately been acknowledged as a grave concern, is the issue of mental health, the cause of which has almost been looked away. Completely disregarded, with the layoffs, the not-so-headstrong employees, who are already troubled by the adverse effects of lockdown, might resort to extreme measures. Employees get depressed, and they may commit suicide! Depression at the workplace has a serious economic consequence (Shani \& Pizam, 2009). The various survey has conducted in the USA, the UK, and Canada on employees' mental health issues, where the results showed a notable economic impact on organization performance and financial loss due to employees' depression (Gilmour \& Patten, 2007; Shani \& Pizam, 2009).

Despite the increasing frequency of the global phenomenon and its impact yet the workplace depression and its economic impact are underdeveloped (West, Lee, \& Poynton, 2012). Less working hours or even no work due to sudden natural disaster or political reasons, increase depression among employees. Previous studies showed that depression among workers has a 
serious impact on employee turnover among organizations (Ratanasiripong et al., 2016). The Malaysian Mental Health Association (MMHA) is urging employers to pay heed to the mental health needs of their staff and to view workplace depression as a legitimate problem (MUTHIAH, 2018). As per to the Centers for Disease Control and Prevention (CDCP) statement (Stewart et al., 2003), depression outcomes, 200 million lost workdays in the U.S.A each year, and consequently, employers could lose USD17-44 billion in efficiency and insurance payments. Depression is a key cause of infirmity, absenteeism, and yield loss among working-age adults. In a 3-month cycle alone, the CDCP projected patients with depression miss an average of 4.8 workdays and suffer 11.5 days of reduced productivity. Depression is not just a disease or a dilemma on paper. Chances are 1 in 10 people you know undergo from some degree of depression - the CDCP reports that in a given year, $9.5 \%$ of the adult population will suffer from a depressive illness. Employees with depression could have adverse effects on company's performance and productivity in the long run ( $\mathrm{Li}, 2020)$.

\section{Job Anxiety}

According to Ivandic et al. (2017), employee performance, work-life, and individual life is highly influenced by one the individual burden of workplace depression and job anxiety. Gilmour and Patten (2007) mentioned that past research showed that work stress and employee performance is linked to employee depression and other psychological disorders. Yawalkar and Sonawane (2017) studied the relationship between segment factors and the work-life balance of a few police personnel from the Jalgaon region police office. They additionally studied work-life balance issues against the different segment factors and found that poor work-life balance prompts errors at the workplace, increases mistakes, and has a pessimistic effect on an individual's wellbeing. Richert-Kazmierska and Stankiewicz (2016) led a study to investigate the effect of old age group on the appraisal of work-life balance by laborers. The outcomes showed statistically significant findings. Employees falling in the older age group are bound to demonstrate the upkeep of worklife balance. They examined different autonomous factors to quantify human resources management rehearses like profession and improvement, preparing and advancement execution evaluation, reward and compensation, and health and wellbeing and tried it against the reliant variable representative maintenance (Limbachiya \& Gupta, 2020).

Job stress or anxiety at the workplace is a hindrance factor that captures the extent to which employees suffer mentally or physically from their job situation. It might manifest as fear about the amount of work they have to accomplish or experiences of a tight feeling in their chests when they think about work. Therefore, we can conceptualize anxiety among employees is a catalyst that hinders or compromises employees' organizational functioning, potentially prompting negative thoughts about their job future (De Clercq et al., 2020; Quade, Perry, \& Hunter, 2019).

\section{Hypothesis Development and Conceptual Framework}

Based on the above discussions, the subsequent hypotheses have drawn for further tests as presented in Table 1. Figure 1 displays the conceptual framework of the study. 
Table 1

Hypothesis Development

\begin{tabular}{ll}
\hline Hypothesis & \multicolumn{1}{c}{ Description } \\
\hline H1 & COVID-19 has a negative impact on retail employees' salary \\
H2 & COVID-19 has a negative impact on retail employees' layoff \\
H3 & COVID-19 has a negative effect on retail employees' depression \\
H4 & COVID-19 has a negative effect on retail employees' anxiety \\
H5a & Depression mediates the relationship between COVID-19 and retail employees' salaries. \\
H5b & Depression mediates the relationship between COVID-19 and retail employees' layoffs. \\
H6a & Job Anxiety mediates the relationship between COVID-19 and retail employees' salaries. \\
H6b & Job Anxiety mediates the relationship between COVID-19 and retail employees' layoffs. \\
\hline
\end{tabular}

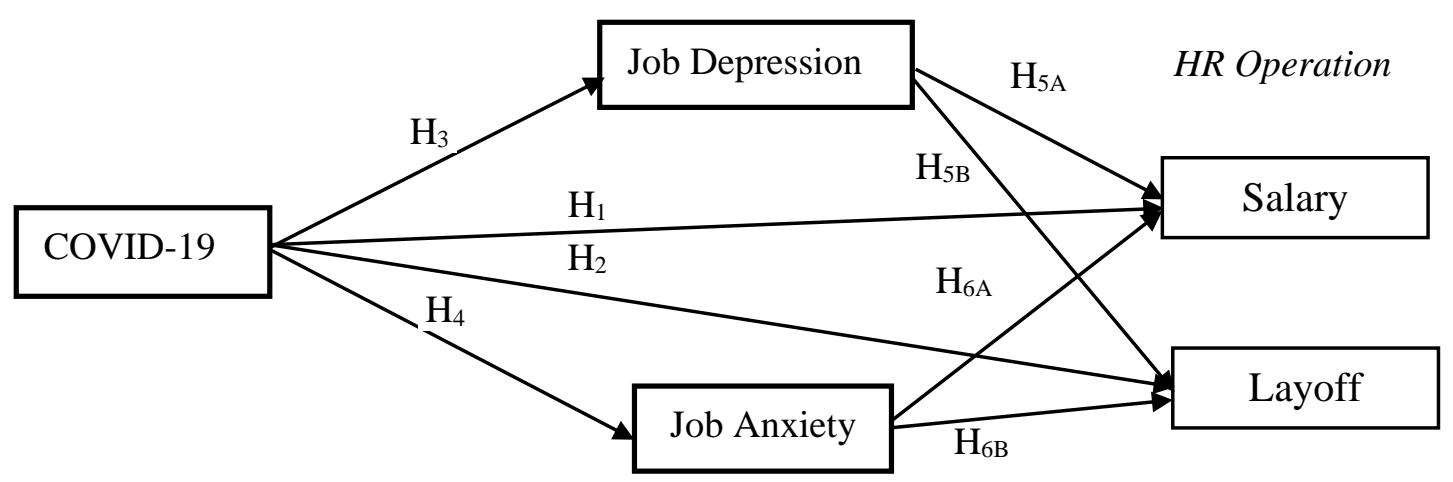

Figure 1. Conceptual framework

\section{Methodology}

\section{Measurement Framework}

The survey tool is intended to identify highly reliable and valid measurements derived from previous studies. The preliminary draft of the questionnaire has been reviewed by retail experts, retail employees, and academics, and recommendations were sought to enhance the reliability and accuracy of the questionnaire. The survey was then developed on the basis of the insight. A total of 330 retail workers were requested via WhatsApp, Facebook, and Instagram to complete the specified online survey form. However, the research model in question consists of five constructs, including COVID-19, Job Depression, Job Anxiety, Salary, and Layoff. Survey tools have been developed using standardized methods. All the measuring factors of these five constructs are adapted from past research and updated in accordance with the current research to ensure that all the elements are valid, illustrating the concepts of proportionality. An online survey was formed to collect data to validate the designs in the research system. Seven-point Likert scale (i.e., $1=$ Strongly Disagree to $7=$ Strongly Consensual) is used to measure items to reflect the level of agreement between survey respondents. The questionnaire was developed using Bahasa Melayu (BM) and English. As the majority of retail employees speak BM, translation was therefore used for this study (Brislin, 1970). Furthermore, a method widely used in cultural surveys to test the accuracy of the language is asked for the translation. 
Out of the 330 distributed questionnaires, 305 were returned. This made up the response rate of $92.42 \%$. In view of that, the rate of response is sufficient for SEM analysis. As the survey form filled up on time, thus no missing value found. However, The Mahalanobis distance was determined based on a total of 27 observed items. The Mahalanobis analysis successfully identified 15 outliers that were deleted permanently, leaving 290 datasets to be used for further analysis. To examine the relationships, all measurement items were standardized, and missing values were substituted by sample means to test validity, reliability, and statistical power. Temme, Kreis, and Hildebrandt (2006) mentioned, the bootstrapping technique estimates the estimator sampling distribution by re-sampling with substitution from the original sample to obtain more consistent results. Thus, in the current study bootstrapping method was used to analyze Job Depression and Job anxiety roles in the relationship between independent and dependent variable.

\section{Sample Size Determination}

As this research uses a partial least square method to structural equation modeling, the minimum sample size required is determined on the basis of the number of paths, i.e., the number of arrows that end to the latent variable constructs, in order to ensure an accurate sample size, the researcher considered the proposed method of Marcoulides and Saunders (2006). Although the partial least square approach can handle small sample sizes, researchers have suggested in various past research that a sample size of 100 to 200 is typically a good set up point in carrying out path modeling (Hoyle, 1995). In order to compile data in the research framework, an Online Survey has been developed. For a total of 27 items, this study considered 290 valid responses to the final analysis.

\section{Sample and Data Collection}

Convenience sampling has used for data collection. Google survey form link was distributed by using social media platforms along with WhatsApp, and face to face interview. Due to the MCO issue, it was obvious to collect data through the online survey form (Sekaran, 2003) have shown that performing a survey would be useful to describe the characteristics of a large population. In this regard, a total of 330 questions were received from Malaysia's Klang Valley area, and only 290 valid responses for data analysis were selected. In March and April 2020, data were collected for this report.

\section{Data Analysis and Findings \\ Data Analysis Software}

Primarily in this research, the researcher has used SPSS version 24.0; besides this, To examine the relationships among the main constructs by adopting the partial least squares (PLS) technique, SmartPLS 3.2.4 (Ringle, Wende, \& Becker, 2015) was utilized to assess the measurement model and structural model. PLS analysis was chosen because it can assess all paths simultaneously and does not need a large sample size (Genfen \& Straub, 2000; Santos \& Barclay, 1995).

\section{Descriptive Analysis}

An analysis of demographic information related to this study provided participants with additional insight. Demographic data in Table 2 illustrates the responses collected from the retail employees who are working in the Klang Valley area. Table 1 shows that male retail employees' number is higher than female employees, 175 (60.3\%) of the respondents were male, and 115 
(39.7\%) were female. The majority age of these retail staffs was 16 to 25 years old $152(52.40 \%)$, followed by the age of $26-35$ years old 70 (24.10\%), 36 - 45 years old 41(14.10\%), $46-55$ years old $19(6.60 \%)$, and the lowest retail employee's age group was 56 years and above were 8 $(2.80 \%)$. Among these respondents, $48.30 \%$ of retail staffs were foreigners, and the rest, $51.70 \%$ were local. Additionally, most of the respondents' educational qualification was STPM 89 (30.70\%), followed by a diploma $82(28.30 \%)$, SPM $76(26.20 \%)$, Bachelor $33(11.40 \%)$, and masters graduate was 10 (.3.40\%). Furthermore, respondents were asked about their job types; $51.40 \%$ were full-time employees followed by $43.10 \%$ part-time staffs, and the rest of the retail employees were contractual, 5.50\%. Finally, they were asked about their experiences in retail sector, $151(52.10 \%)$ mentioned that they have 1-5 years of service experience in the retail industry; whereas, 95 (32.80\%) said they had worked 6-10 years in retail, followed by 11-15 years' service duration had $28(9.70 \%)$ and 16 and above years of job experience in retail was 16 $(5.50 \%)$.

Table 2

Demographic Profile

\begin{tabular}{llcc}
\hline Measure & Item & Frequency & Percentage \\
\hline Gender & Male & 175 & 60.3 \\
Age & Female & 115 & 39.7 \\
& $16-25$ & 152 & 52.4 \\
& $26-35$ & 70 & 24.1 \\
& $36-45$ & 41 & 14.1 \\
Nationality & $46-55$ & 19 & 6.6 \\
& 56 and above & 8 & 2.8 \\
Education & Local & 150 & 51.7 \\
& Foreigner & 140 & 48.3 \\
& SPM & 76 & 26.2 \\
Types of Jobs & STPM & 89 & 30.7 \\
& Diploma & 82 & 28.3 \\
Service Duration & Bachelor & 33 & 11.4 \\
& Masters & 10 & 3.4 \\
& Full Time & 149 & 51.4 \\
& Part-Time & 125 & 43.1 \\
& Contractual & 16 & 5.5 \\
\hline
\end{tabular}

\section{Measurement Model}

Indicator reliability

Table 3 illustrates the indicator reliability values for all the variables are ranged between .72-.92, so it can be concluded that the indicator reliability is confirmed (Hulland, 1999). 
Table 3

The Indicator Reliability

\begin{tabular}{|c|c|c|c|}
\hline $\begin{array}{l}\text { Construct } \\
\text { (Latent Variable) }\end{array}$ & Indicators & Loadings & $\begin{array}{c}\text { Indicators Reliability } \\
\text { (Loadings2) }\end{array}$ \\
\hline \multirow{6}{*}{ COVID-19 } & Cov_1 & .81 & .65 \\
\hline & Cov_2 & .77 & .59 \\
\hline & Cov_3 & .85 & .72 \\
\hline & Cov_4 & .85 & .72 \\
\hline & Cov_5 & .80 & .64 \\
\hline & Cov_6 & .76 & .58 \\
\hline \multirow{4}{*}{ Job Depression } & Dep_1 & .72 & .53 \\
\hline & Dep_2 & .79 & .62 \\
\hline & Dep_3 & .73 & .53 \\
\hline & Dep_4 & .82 & .67 \\
\hline \multirow{5}{*}{ Job Anxiety } & Anx__1 & .92 & .86 \\
\hline & Anx_2 & .77 & .60 \\
\hline & Anx_3 & .86 & .74 \\
\hline & Anx_4 & .81 & .66 \\
\hline & Anx_5 & .76 & .58 \\
\hline \multirow{6}{*}{ Salary } & Sal_1 & .80 & .65 \\
\hline & Sal_2 & .81 & .65 \\
\hline & Sal_3 & .82 & .67 \\
\hline & Sal_4 & .86 & .75 \\
\hline & Sal_5 & .85 & .72 \\
\hline & Sal_6 & .83 & .69 \\
\hline \multirow{6}{*}{ Layoff } & Lay_1 & .81 & .65 \\
\hline & Lay_2 & .80 & .64 \\
\hline & Lay_3 & .84 & .71 \\
\hline & Lay_4 & .75 & .57 \\
\hline & Lay_5 & .85 & .72 \\
\hline & Lay_6 & .84 & .72 \\
\hline
\end{tabular}

Figure 2 shows the entire results for the hypothesized model. According to Genfen, Karahanna, and Straub (2003), a good model fit in PLS is presented when there are significant path coefficients, acceptable $\mathrm{R}^{2}$ values, and good construct reliability. However, Chin (1998) stated thar the model predictability reflected by the values of $\mathrm{R}^{2}$ is another important strength determinant of the model. The reliability $(\alpha)$, composite reliability (CR), and average variance extracted (AVE), shown in Table 4, are the three major measurements utilized in this research. To test the convergent validity, each construct's value (CR and $\alpha$ ) should be higher than .70 (Hair Jr, Hult, Ringle, \& Sarstedt, 2016). This study shows that the CR values ranging from .85 to .93 , and Cronbach $(\alpha)$ values from .85 to .93 (Hair et al., 2006) has given the rule of thumb for the outer loading of each item should be higher than .50. Although the loading of more than .70 reflects more variance. The given threshold for the AVE value is equal to or above .50, is appropriate (Hair, Ringle, \& Sarstedt, 2013). Thus, AVE for this current study ranges from .59 to .69. The test result in the current study shows good reliability, which confirms that the measurement model maintained sufficient convergent validity.

Initially, to accomplish discriminant validity, construction loadings shall be high on themselves and low on other constructs (Vinzi, Trinchera, \& Amato, 2010). Not only that, according to Henseler, Jörg, Hubona, and Ray (2016), the square root value of the AVE of each construct is higher than its correlation values with other constructs, confirming the discriminant validity. Hence, in the current study, as shown in Table 4, the results reported good discriminating validity of the measuring model, which indicated that the recent study meets Fornell and 
Larcker's (1981) Criterion. Besides, cross-loading of all items were examined, and the result indicated the loadings of each construct represent the higher value of each item within the constructs. The distinctness of the construction is concentrated with the discriminating validity of the phenomenon taken by a construct that is unique and not the other constructs represented in the framework (Hair et al., 2013).

Table 4

Construct Reliability and Convergent Validity

\begin{tabular}{|c|c|c|c|c|c|c|c|c|}
\hline Variables & $\alpha$ & $\mathrm{CR}$ & AVE & COVID-19 & Job Anxiety & Job Depression & Layoff & Salary \\
\hline COVID-19 & .92 & .92 & .66 & .81 & & & & \\
\hline Job Anxiety & .92 & .92 & .69 & .42 & .83 & & & \\
\hline Job Depression & .85 & .85 & .59 & .64 & .36 & .76 & & \\
\hline Layoff & .93 & .93 & .67 & .53 & .54 & .47 & .82 & \\
\hline Salary & .93 & .93 & .69 & .76 & .44 & .63 & .69 & .83 \\
\hline
\end{tabular}

\section{Heterotrait-Monotrait Correlation Ratio (HTMT)}

The Heterotrait-Monotrait Correlation Ratio (HTMT) Discrimination of validity between two reflective constructs will be confirmed if the HTMT value is less than .90 . Table 5 reveals, the HTMT values of the current study that did not reach the .90 limits, so the discrimination validity could also be inferred for all systems (Henseler et al., 2016).

Table 5

Heterotrait-Monotrait Correlation Ratio (HTMT)

\begin{tabular}{|c|c|c|c|c|c|}
\hline Variables & COVID-19 & Job Anxiety & Job Depression & Layoff & Salary \\
\hline \multicolumn{6}{|l|}{ COVID-19 } \\
\hline Job Anxiety & .41 & & & & \\
\hline Job Depression & .64 & .35 & & & \\
\hline Layoff & .53 & .54 & .46 & & \\
\hline Salary & .76 & .43 & .63 & .69 & \\
\hline
\end{tabular}

\section{Structural Model}

The structural model reflects the relationship between the constructs or the latent variables that were hypothesized in this study. Collinearity issue of the structured model (VIF), values of all the constructs assess collinearity issues in a structured model. The common method bias (VIF) value should be lower or equal to 5 (Kock, 2015). The VIF values for this study fall in between 1.95 to 3.92 , and none of the values exceed the threshold value. The coefficient of determination $\left(\mathrm{R}^{2}\right)$ represents the variance in the independent variable by independent constructs (Elliott \& Woodward, 2007). Both path coefficients and $\mathrm{R}^{2}$ scores were determined by the structural model analysis. According to Morard, Balu, and Brasoveanu (2016), $\mathrm{R}^{2}$ values of .67, .33, and .17 are considered to be strong, moderate, and weak, respectively. The t-value $>1.96$ is significant at $p<$ .05 and t-value $>2.58$ is significant at $p<.01$ (Hair, Sarstedt, Ringle, \& Gudergan, 2017). Figure 2 shows the $\mathrm{R}^{2}$ value in this model that is $63.20 \%$ for Salary and $42.20 \%$ for Layoff, which indicates a moderate level of predictive accuracy. Besides, Job Depression shows a moderate level of predictive accuracy with $41.80 \%$; whereas, low predictive accuracy has shown in Job Anxiety $17.70 \%$, which indicates weak predictive accuracy. Regarding the Predictive Relevance $\left(Q^{2}\right)$ Effect Sizes, the size of the effect of latent variables was assessed through cross-validated redundancy $\mathrm{Q}^{2}$ (Henseler, Ringle, \& Sinkovics, 2009). The predictive relevance that is in the 
model of the value of $\mathrm{Q}^{2}$ is higher than zero is deemed as the existence of predictive relevance in the model (Chin, 1998). The current study met the rule of thumb (see Table 6). The effect Sizes $\mathrm{F}^{2}$ are greater than .02 .

Table 6

Structured Model Results

\begin{tabular}{|c|c|c|c|c|c|c|}
\hline \multirow{2}{*}{ Variables } & \multicolumn{4}{|c|}{ VIF and $\mathrm{f} 2$} & \multirow{2}{*}{$\mathrm{R} 2$} & \multirow{2}{*}{ Q2 } \\
\hline & Job Anxiety & Job Depression & Layoff & Salary & & \\
\hline & 1.000 & 1.000 & & & & \\
\hline COVID-19 & $(.21)$ & $(.71)$ & $1.84(.07)$ & $1.84(.47)$ & & \\
\hline Job Anxiety & & & $1.23(.19)$ & $1.23(.03)$ & .17 & .14 \\
\hline Job Depression & & & $1.74(.02)$ & $1.74(.07)$ & .41 & .32 \\
\hline Salary & & & & & .63 & .49 \\
\hline Layoff & & & & & .42 & .23 \\
\hline
\end{tabular}

\section{Model Fit}

In general, in SmartPLS, SRMR is measured to check the model fit. When SRMR $=<.08$, then the study model is considered as a good fit, with a lower SRMR being a better fit (Hu \& Bentler, 1998). This study model's SRMR is .63 which indicates a good fit (see Table 7), whereas the ChiSquire value is equal to 847.65 and NFI is .86. Though the NFI value is below the .90 by considering all other thresholds, including the result of SRMR and Chi-Square, it can be reported that the proposed model is a good fit.

Table 7

Model Fit

\begin{tabular}{lll}
\hline Fit Indices & Estimated Model & Ideal Threshold \\
\hline SRMR & 0.06 & $<.08$ \\
Chi-Square & 847.65 & Upper is better \\
NFI & 0.86 & $>.90$ \\
\hline
\end{tabular}

\section{Mediation Analysis}

\section{Job Depression}

Table 8 shows the direct and indirect effects. The bootstrapping results show that the direct effect is significant. Whereas, the Indirect Effects show that Jobs Depression partially mediates the relationship between COVID-19 and Salary. Moreover, Job depression does not mediate the relationship between COVID-19 and Layoff, as their direct effect is only statistically significant.

Table 8

Mediation analysis of Job Depression

\begin{tabular}{|c|c|c|c|c|}
\hline & $\beta$ & (STDEV) & $t$ & $p$ \\
\hline \multicolumn{5}{|l|}{ Direct Effect } \\
\hline COVID-19 -> Salary & .19 & .05 & 3.73 & $.001 *$ \\
\hline \multicolumn{5}{|l|}{ Indirect Effect } \\
\hline COVID-19 -> Job Depression -> Salary & .14 & .05 & 2.799 & $.005^{*}$ \\
\hline COVID-19 -> Job Depression -> Layoff & .10 & .05 & 1.882 & $.060^{* *}$ \\
\hline
\end{tabular}

\section{Job Anxiety}

Table 9 shows the direct and indirect effects. The bootstrapping results show that the direct effect is significant. Whereas, Indirect Effects show that Jobs Anxiety partially mediates the relationship 
between COVID-19 and Salary. Job anxiety also partially mediates the relationship between COVID-19 and Layoff.

Table 9

Mediation analysis of Job Anxiety

\begin{tabular}{lcccc}
\hline & $\beta$ & $($ STDEV) & $t$ & $p$ \\
\hline Direct Effect & & & & \\
COVID-19 -> Layoff & .25 & .06 & 4.06 & $.001^{*}$ \\
Indirect Effect & & & & \\
COVID-19 -> Job Anxiety -> Layoff & .15 & .03 & 4.19 & $.001^{*}$ \\
COVID-19 -> Job Anxiety -> Salary & .05 & .02 & 2.38 & $.017^{*}$ \\
\hline
\end{tabular}

* Significant at $p<.000$

\section{The Summary of Findings and Hypothesis Testing Result}

This study employed covid-19, job depression and job anxiety to examine the impact on HR operation namely Salary and Layoff. Firstly, covid-19 was found to have a significant effect on retail employees' salary ( $\mathrm{H}_{1}$ was supported), besides covid-19 also has a significant effect on retail employees' layoff $\left(\mathrm{H}_{2}\right.$ was supported). In this study, respondents agreed that covid-19 has a significant effect in increasing job depression and job anxiety $\left(\mathrm{H}_{3}\right.$ and $\mathrm{H}_{4}$ were supported). However, the result showed that job depression mediates the relationship between covid-19 and salary $\left(\mathrm{H}_{5 \mathrm{~A}}\right.$ was supported) but retail employees' job depression did not mediate the relationship between covid-19 and layoff ( $\mathrm{H}_{5 \mathrm{~B}}$ was not supported). Besides, as retail employees are passing their time with anxiety during $\mathrm{MCO}, \mathrm{CMCO}$ and $\mathrm{RMCO}$ yet this job anxiety mediates the relationship among covid-19, salary and layoff.

As far as the hypothesis testing is concerned, Figure 2 and Table 10 illustrate the path coefficient $(\beta), t$-statistics, and $p$-value of each hypothesis. Based on the analysis, all the hypotheses are found to be significant, thus supported. $\mathrm{H}_{1}(\beta=.56, t=7.89)$ indicates the path between COVID-19 and retail employees' salaries, indicating the positive and significant relationship between them. $\mathrm{H}_{2}(\beta=.27, t=2.97)$ shows the path between COVID-19 and retail employees' layoff; and found a significant and positive relationship between them. $\mathrm{H}_{3}(\beta=.64, t$ $=13.82$ ) demonstrates the positive relationship between COVID-19 and retail employees' Job depression. $\mathrm{H}_{4}(\beta=.42, t=6.81)$ explains that COVID-19 has a positive and significant influence on retail employee Job anxiety. $\mathrm{H}_{5 \mathrm{~A}}(\beta=.14, t=2.80)$ prescribed the significant and positive relationship between COVID-19 and retail employees' salaries through Job Depression. Besides, $\mathrm{H}_{5 \mathrm{~B}}(\beta=.10, t=1.89)$, which is statistically significant and positive in the relationship built. However, $\mathrm{H}_{6 \mathrm{~A}}(\beta=.14, t=2.80)$ prescribed the significant and positive relationship between COVID-19 and retail employees' salaries through Job Depression. Besides, $\mathrm{H}_{5 \mathrm{~B}}(\beta=.10, t=1.89)$ is not statistically significant. However, $\mathrm{H}_{6 \mathrm{~A}}(\beta=.05, t=2.35)$ prescribed the significant and positive relationship between COVID-19 and retail employees' salaries. Lastly, Job anxiety $\mathrm{H}_{6 \mathrm{~B}}$ $(\beta=.15, \mathrm{t}=4.25)$, mediates the relationship between COVID-19 and Layoff. 
Table 10

Hypothesis Results

\begin{tabular}{llcccc}
\hline Hypothesis & Corresponding Path & $\beta$ & $t$ & $p$ & Judgment \\
\hline H1 & COVID-19 -> Salary & .56 & 7.89 & .001 & Supported \\
H2 & COVID-19 -> Layoff & .27 & 2.97 & .003 & Supported \\
H3 & COVID-19 -> Job Depression & .64 & 13.82 & .001 & Supported \\
H4 & COVID-19 -> Job Anxiety & .42 & 6.81 & .001 & Supported \\
H5a & COVID-19 -> Job Depression -> Salary & .14 & 2.80 & .005 & Supported \\
H5b & COVID-19 -> Job Depression -> Layoff & .10 & 1.89 & $.059^{*}$ & Not supported \\
H6a & COVID-19 -> Job Anxiety -> Salary & .05 & 2.35 & .019 & Supported \\
H6b & COVID-19 -> Job Anxiety -> Layoff & .15 & 4.25 & .001 & Supported \\
\hline
\end{tabular}

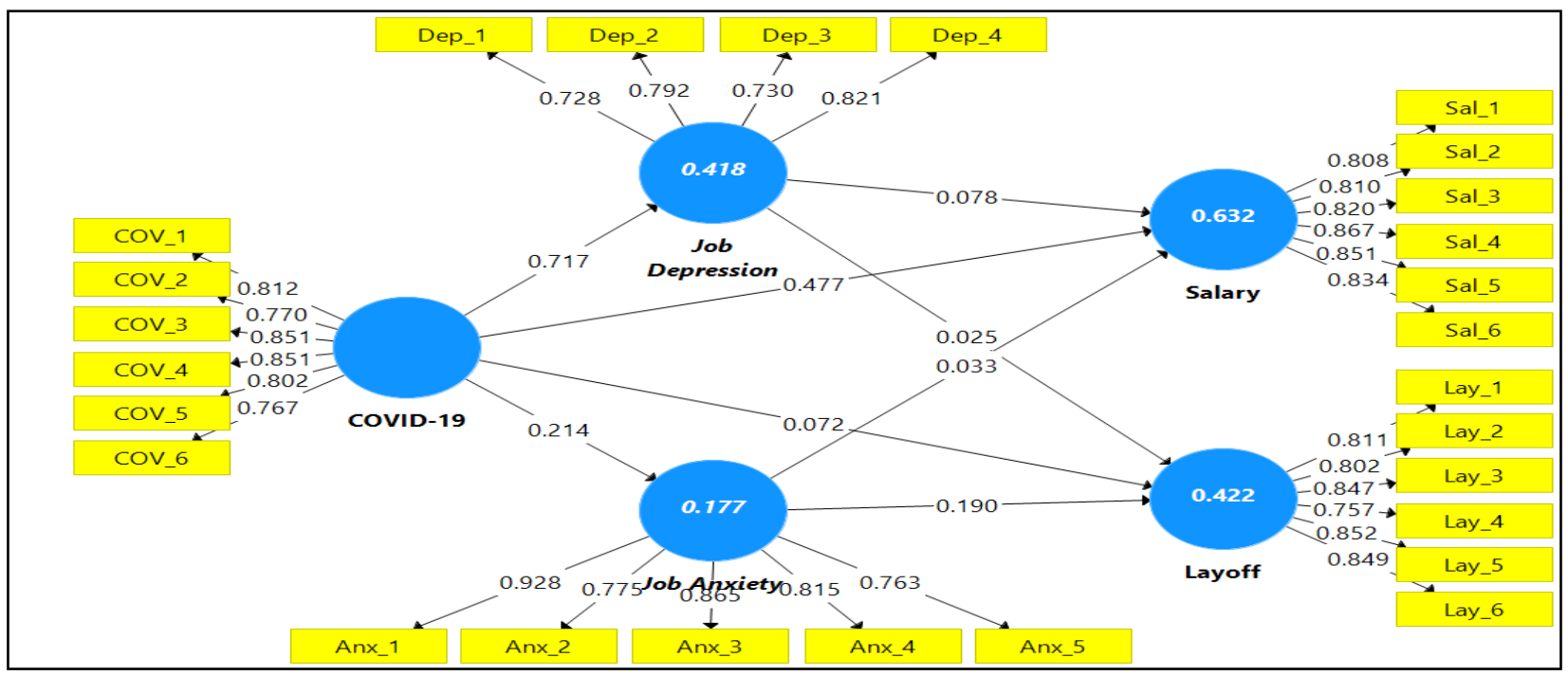

Figure 2. Structural Equation Model

\section{Discussion and Conclusion}

The objective of this research was to create a relationship between COVID-19 and the retail HR Operation, namely Salary and Layoff, with the mediating effect of job depression and job anxiety in the Malaysian retail sector in the Klang Valley region. As per the best of the researchers' acquaintance, this is one of the few research and the first comprehensive broad sample analysis to investigate 'COVID-19 and HR Retail Operations in Malaysia. This research was designed to build probable relationships among variables such as COVID-19, job stress, job anxiety, salary, and layoff. Besides, the role of job depression and job anxiety as mediators between Covid-19 and HR operation is a step forward in this field. The aim of this research was to bridge the gap in the existing literature on the effect of the findings and the level of satisfaction of retail employees in the current pandemic situation. Given this, an assessment was carried out of the previous research in the areas of Covid-19, the job stimulation of workers (e.g., job depression and job anxiety), and the HR operation (e.g., salary and layoff). Based on the early results of the empirical studies, the model was developed, and it was found that Covid-19 had a positive and significant direct effect on Salary and Layoff. Subsequently, the mediating relationship was integrated into a model where job depression and job anxiety were used as mediators. Theoretically, it is impossible to claim the superiority of any kind, and so empirical tests have been carried out. In order to achieve this goal, the PLS technique data analysis was adopted.

The results of this study indicate that in the present Covid-19 situation, Malaysia retailers can minimize jobs depression and anxiety by paying their workers on time and not explicitly laying off employees. A regular payment scheme with job protection would, in turn, increase the 
efficiency and morale of workers in the ordinary situation. As a result of the global impact of Covid-19, the global economy is undergoing enormous turmoil. For this consequence, Malaysian retailers also will face economic weaknesses. Thus, if retailers take the right approach, the potential staff turnover costs may be reduced, and the desired efficiency improved. The managerial purpose of this research is to help policymakers of the Malaysian retail association and retailers scabbing their attention on HR operations so that they can effectively manage their workers and ensure employees not to be unhappy in the coming new normal situation. Ultimately, the study results provide professionals with recommendations for what is required to alleviate job depression and anxiety at work, ensuring prompt payments and job security.

The present study used the convenience survey method and focused on a particular geographical area which is Klang Valley. Thus, a larger sample size would provide a more realistic picture of the impact of Covid-19 on HR operations. Future research can consider the entire retail sector of the country and add control variables as moderators to examine whether relations differ based on the demographic profile of the respondent with regard to nationality, age, and gender, etc.

\section{References}

Baker, S. R., Farrokhnia, R. A., Meyer, S., Pagel, M., \& Yannelis, C. (2020). How does household spending respond to an epidemic? consumption during the 2020 covid-19 pandemic (No. w26949). National Bureau of Economic Research.

Basari, M. A. M. D., Yazid, M. F., \& Shamsudin, M. F. (2020). Suggestion for retailers during and post covid-19 downturn. Journal of Postgraduate Current Business Research, 1(1).

Brislin, R. W. (1970). Back-translation for cross-cultural research. Journal of Cross-Cultural Psychology, 1(3), 185-216.

Chaudry, M. S., Sabir, H. M., Rafi, N., \& Kalyar, M. N. (2011). Exploring the relationship between salary satisfaction and job satisfaction: A comparison of public and private sector organisations. The Journal of Commerce, 3(4), 1-14.

Chin, W. W. (1998). Commentary: Issues and opinion on structural equation modeling. JSTOR, 22(1). Retrieved from https://www.jstor.org/stable/249674?seq=1.

Craven, M., Liu, L., Mysore, M., \& Wilson, M. (2020). COVID-19: Implications for business. Executive Briefing, COVID-19: Briefing note, McKinsey \& Company. Retrieved from www.google.com. Assessed on 10/7.

Davidson, H. (2020). First Covid-19 case happened in November, China government records show-report. The Guardian, London, England.

De Clercq, D., Azeem, M. U., Haq, I. U., \& Bouckenooghe, D. (2020). The stress-reducing effect of co-worker support on turnover intentions: Moderation by political ineptness and despotic leadership. Journal of Business Research, 111, 12-24.

Elliott, A. C., \& Woodward, W. A. (2007). Statistical analysis quick reference guidebook: With SPSS examples. Sage Publication.

Fornell, C., \& Larcker, D. F. (1981). Structural equation models with unobservable variables and measurement error: Algebra and statistics. Journal of Marketing Research, 18(3), 382-388.

Genfen, D., \& Straub, D. (2000). Managing User Trust in B2C e-services quarterly. Electronic publication (Oct. 2000).

Gefen, D., Karahanna, E., \& Straub, D. W. (2003). Trust and TAM in online shopping: An integrated model. MIS Quarterly, 27(1), 51-90.

Gilmour, H., \& Patten, S. B. (2007). Depression at work. Perspectives on Labour and Income, 8(11), 19-31.

Hair, J. F., Black, W. C., Babin, B. J., Anderson, R. E., \& Tatham, R. L. (2006). Analysis Multivariate data analysis. Upper Saddle River: NJ: Pearson Prentice Hall.

Hair, J. F., Hult, G. T. M., Ringle, C., \& Sarstedt, M. (2016). A primer on partial least squares structural equation modeling (PLS-SEM). Sage publications.

Hair, J. F., Joseph F., Ringle, C. M., \& Sarstedt, M. (2013). Partial least squares structural equation modeling: Rigorous applications, better results and higher acceptance. Long Range Planning, 46(1-2), 1-12. 
Hair, J. F., Sarstedt, M., Ringle, C. M., \& Gudergan, S. P. (2017). Advanced issues in partial least squares structural equation modeling. Sage Publications.

Haak, T. (2017). HR Operations is the most important part of HR | By the HR Trend Institute. Retrieved April 11, 2020, from HR Trend Institute website: https://hrtrendinstitute.com/2017/02/20/hr-operations-in-the-lift/

Hasanat, M. W., Hoque, A., Shikha, F. A., Anwar, M., Hamid, A. B. A., \& Tat, H. H. (2020). The Impact of Coronavirus (Covid19) on E-Business in Malaysia. Asian Journal of Multidisciplinary Studies, 3(1), 85-90.

Henseler, J., Ringle, C. M., \& Sinkovics, R. R. (2009). The use of partial least squares path modeling in international marketing. In R. R. Sinkovics \& P. N. Ghauri (Eds.), New challenges to international marketing (pp. 277-319). (Advances in International Marketing, Vol. 20), Emerald Group Publishing Limited, Bingley.

Henseler, J, Hubona, G., \& Ray, P. A. (2016). Using PLS path modeling in new technology research: Updated guidelines. Industrial Management and Data Systems, 116(1), 2-20.

Hoyle, R. H. (1995)(Ed.). The structural equation modeling approach: Basic concepts and fundamental issues. In Structural equation modeling: Concepts, issues, and applications (pp. 1-15). Thousand Oaks, CA, US: Sage Publications, Inc.

Hu, L., \& Bentler, P. M. (1998). Fit indices in covariance structure modeling: Sensitivity to underparameterized model misspecification. Psychological Methods, 3(4), 424-453.

Hulland, J. (1999). A new antihypertensive drug ameliorate insulin resistance. Strategic Management Journal, 20, 195-204.

Hung, L. M., Lee, Y. S., \& Lee, D. C. (2018). The moderating effects of salary satisfaction and working pressure on the organizational climate, organizational commitment to turnover intention. International Journal of Business and Society, 19(1), 103-116.

Iqbal, S., Guohao, L., \& Akhtar, S. (2017). Effects of job organizational culture, benefits, salary on job satisfaction ultimately affecting employee retention. Review of Public Administration and Management, 5(3).

Ivandic, I., Kamenov, K., Rojas, D., Cerón, G., Nowak, D., \& Sabariego, C. (2017). Determinants of work performance in workers with depression and anxiety: A cross-sectional study. International Journal of Environmental Research and Public Health, 14(5), 466

Judge, T. A., Cable, D. M., \& Higgins, C. A. (2000). The employment interview: A review of recent research and recommendations for future research. Human Resource Management Review, 10(4), 383-406.

Kock, N. (2015). Common method bias in PLS-SEM: A full collinearity assessment approach. International Journal of ECollaboration (Ijec), 11(4), 1-10.

Li, N. N. (2020). Is your employee suffering? Telltale signs of depression in the workplace. Forbes.

Limbachiya, V., \& Gupta, A. (2020). A study on work life balance and retention on retail industry in Ahmedabad abstract: Introduction: Review of literature. Studies in Indian Place Names, 40(08), 89-99.

Loo, C. (2020). CMCO ends June 9, Recovery MCO from June 10 to Aug 31 (Updated). Retrieved from https://www.thesundaily.my/home/cmco-ends-june-9-recovery-mco-from-june-10-to-aug-31-updated-EM2538754. June 23, 2020.

Malik, M. I., Ahmad, A., \& Hussain, S. (2010). How downsizing affects the job satisfaction and life satisfaction of layoff survivors. African Journal of Business Management, 4(16), 2564-3570.

Marcoulides, G. A., \& Saunders, C. (2006). Editor's comments: PLS: A silver bullet? MIS Quarterly, 30(2), iii-ix. https://doi.org/10.2307/25148727

McKibbin, W. J., \& Fernando, R. (2020). The global macroeconomic impacts of COVID-19: Seven scenarios. SSRN Electronic Journal, O(2), 1-45. https://doi.org/10.2139/ssrn.3547729

Meyer, S. (2020). Understanding the Covid-19 effect on online shopping behavior. The BigCommerce Blog.

Morard, B., Balu, F. O., \& Brasoveanu, L. O. (2016). Using Pls methodology for understanding commodity market behaviour and improving decision-making process. International Journal of Management and Applied Science, 2(7), 193-201.

MUTHIAH, W. (2018). Stress and workplace depression must be addressed, says mental health association. Retreived from https://www.thestar.com.my/news/nation/2018/10/02/stress-and-workplace-depression-must-be-addressed-says-mentalhealth-association.

Perimbanayagam, K. (2020, April 29). Government urged to table Covid-19 bill to save retail, services and manufacturing sectors. New Straits Times Press (M) Bhd. https://www.nst.com.my/news/nation/2020/04/588576/government-urged-tablecovid-19-bill-save-retail-services-and

Pohlan, L. (2019). Unemployment and social exclusion. Journal of Economic Behavior and Organization, 164, $273-299$.

Ponnusamy, S. (2019). What is HR Analytics? Retrieved from azcentral website: https://yourbusiness.azcentral.com/hroperations-12325.html (April 11, 2020).

Quade, M. J., Perry, S. J., \& Hunter, E. M. (2019). Boundary conditions of ethical leadership: exploring supervisor-induced and job hindrance stress as potential inhibitors. Journal of Business Ethics, 158(4), 1165-1184. https://doi.org/10.1007/s10551017-3771-4 
Ratanasiripong, P., Kaewboonchoo, O., Bell, E., Haigh, C., Susilowati, I., Isahak, M., ... Low, W. Y. (2016). Depression, anxiety and stress among small and medium enterprise workers in Indonesia, Malaysia, Thailand, and Vietnam. International Journal Of Occupational Health and Public Health Nursing, 3(2), 2053-2377.

Reinardy, S. (2012). Job security, satisfaction influence work commitment. Newspaper Research Journal, 33(1), 55-70. https://doi.org/10.1177/073953291203300105

Richert-Kazmierska, A., \& Stankiewicz, K. (2016). Work-life balance: Does age matter? Work, 55(3), 679-688. https://doi.org/doi:10.3233/wor-162435

Ringle, C. M., Wende, S., \& Becker, J. M. (2015). SmartPLS 3. SmartPLS GmbH, Boenningstedt. Retreived from http://www.smartpls.com

Roggeveen, A. L., \& Sethuraman, R. (2020). How the COVID-19 pandemic may change the world of retailing. Journal of Retailing, Advance Online Publication, 96(2), 169-171.

Santos Granero, F., \& Barclay Rey de Castro, F. (1995). Orders and disorders in the Central Jungle: History and economy of a regional space. Lima: Institut français d'études andines. https://doi.org/10.4000 / books.ifea.2530

Sekaran, U. (2003). Research and Markets: Research Methods for Business - A Skill Building Approach. In John Wiley \& Sons (4th ed.).

Shani, A., \& Pizam, A. (2009). Work-related depression among hotel employees. Cornell Hospitality Quarterly, 50(4), 446459. https://doi.org/10.1177/1938965509344294

Sobieralski, J. (Todd), \& Nordstrom, C. R. (2012). An examination of employee layoffs and organizational justice perceptions. Journal of Organizational Psychology, 12(3/4), 11-20.

Stewart, W. F., Ricci, J. A., Chee, E., Hahn, S. R., \& Morganstein, D. (2003). Cost of lost productive work time among us workers with depression walter. The Journal of the American Medical Association, 289(23), 3135-3145

Temme, D., Kreis, H., \& Hildebrandt, L. (2006). PLS path modeling - a software review. Retrieved from http://sfb649.wiwi.huberlin.de

Ting, Y. (1997). Determinants of job satisfaction of municipal government employees. Public Personnel Management, 26(3), 313-334. https://doi.org/10.1177/009102600203100307

Vinzi V.E., Trinchera L., Amato S. (2010) PLS path modeling: From foundations to recent developments and open issues for model assessment and improvement. In V. Esposito Vinzi, W. Chin, J. Henseler, \& H. Wang (Eds.), Handbook of Partial Least Squares (pp. 47-82). Springer Handbooks of Computational Statistics. Springer, Berlin, Heidelberg. https://doi.org/10.1007/978-3-540-32827-8_3

Welt, F. G. P., Shah, P. B., Aronow, H. D., Bortnick, A. E., Henry, T. D., Sherwood, M. W., ... Kirtane, A. J. (2020). Catheterization laboratory considerations during the Coronavirus (COVID-19) pandemic: From the ACC's Interventional Council and SCAI. Journal of the American College of Cardiology, 75(18), 2372-2375. https://doi.org/10.1016/j.jacc.2020.03.021

West, L., Lee, A., \& Poynton, C. (2012). Becoming depressed at work: A study of worker narratives. Journal of Workplace Behavioral Health, 27(3), 196-212. https://doi.org/10.1080/15555240.2012.701184

Yawalkar, V. V., \& Sonawane, M. A. (2017). Impact of demographic variables on work-life balance of police personnel: With reference to Jalgaon Police Department. International Journal of Science, Engineering and Management (IJSEM), 2(9), 2932.

Zahid, S. J. (2020). Covid-19: Malaysian retailers say job cuts, store closures inevitable as 'new normal' bites. Malay Mail. Retrieved from https://www.malaymail.com/news/malaysia/2020/05/06/covid-19-malaysian-retailers-say-job-cuts-closuresinevitable-as-new-normal/1863440 